\title{
Towards Sustainability Framework for Tour Operators as Drivers of Sustainable Tourism Agenda in Kenya
}

\author{
George Ariya $^{1^{*}}$, Catherine Sempele ${ }^{2}$, Grace Nderitu ${ }^{3}$ \\ ${ }^{1}$ Lecturer, University of Eldoret, Department of Tourism and Tour Operations Management, P.O. Box 1125- \\ 30100 Eldoret-Kenya. \\ ${ }^{2}$ Lecturer, University of Eldoret, Department of Hotel and Hospitality Management, P.O. Box 1125-30100 \\ Eldoret-Kenya. \\ ${ }^{3}$ CEO, Ecotourism Kenya, P.O. Box 10146-00100, Nairobi-Kenya.
}

\begin{abstract}
*Corresponding Author: George Ariya, Lecturer, University of Eldoret, Department of Tourism and Tour Operations Management, P.O. Box 1125-30100 Eldoret-Kenya
\end{abstract}

\begin{abstract}
While the academic debate on hotel certification and customer awareness on sustainability practices has been widely documented in Kenya, sustainable certification of tour operators has drawn little attention. However, tour operators could be the principal drivers of the sustainability agenda within tourism value chain. They act as the bridge between client and host destination, influence or make choices on behalf of (potential) clients and suppliers' practices, and may drive positive contribution for sustainable tourism destinations in Kenya. This paper tends to provide a framework on how sustainable certification process may be implemented by placing tour operators at the centre of sustainable tourism value chain. The paper is based on systematic theoretical literature review to present sustainability framework in the early steps of tour operators' certification process in Kenya. The paper concludes that while driving sustainable tourism agenda in Kenya in the overall tourism value chain, tour operators as influencers of suppliers' practices and customers' choice of tourism services, could be the drivers of tourism sustainability agenda within the overall tourism value chain.
\end{abstract}

Keywords: Sustainability Framework, Tour Operators, Drivers, Sustainable Tourism Agenda, Kenya.

\section{INTRODUCTION}

The growth of tourism sector in developing countries like Africa placed heavy burden on the local economies, host cultures and social dynamics as well as on the physical environment. Because of this trend, available literature like Bhandari (2014) calls for responsible management of tourism destinations. Other authors like Akama et al. (2011) also suggest development of tourism certification programs and indicators to attend to social and cultural sustainability. Sustainability issues in the travel industry are increasingly coming under public scrutiny, attracting the attention of financial markets and becoming subject to increasing legislative requirements (Miller and Twining-Ward, 2005). For tour operators in particular, the management of supplier performance is especially critical, since customers rarely differentiate between the activities of an operator and its suppliers (Fontet et al., 2008).

From demand perspective, majority of consumers have developed interest in sustainable holiday products and demand greater social and environmental engagement from destinations and suppliers (Mintel, 2003; Mori, 2000; Tearfund, 2001). For example, Chafe (2004) notes that tourists have become interested in patronizing hotels that are committed to protecting the local environment, and increasingly view local environmental and social stewardship as a responsibility of the businesses they support. Travel sustainability survey by Tui Travel (2010) indicates that although sustainability issues do not rank as highly in holiday booking decision as value for money and destination choice, the survey showed that sustainability is not unimportant. Other authors (Ariya et al., 2017; Boniface and Coope, 2005; Miller, 2003; Yeoman, 2008) also support the idea that consumers make their purchasing decisions on the basis of the environmental, social and economic quality of products and are willing to transfer these habits to the purchase of tourism products. Font and Cochrane (2005) augment that tourists now expect sustainability considerations to be integrated into their holidays. This means that tour operators must operate sustainability to remain competitive. 
The scenario has created concern among tourism product supplies and distributors in the tourism value chain to innovate and distribute tourism products that not only creates value for money but also complied with the principle of sustainability. While attention has been drawn on creating hotel standards through certification and ecolabelling, the contribution of tour operators on sustainability agenda has been overlooked especially in developing countries like Kenya. Previous research indicates that for tourism sector to be more sustainable depends to a large extent on tour operators, which are the main players in the industry (Wijk and Persoon, 2006). This is because they are the key main owners of tourism package and connect suppliers to consumers in the tourism value chain. This central position provides tour operators with power and bargaining dominance over individual suppliers at the destinations. They can also lever their potential for the implementation of product improvements upstream in the production chain because suppliers often have no alternative marketing or distribution channels (Buhalis, 2000; Bastakis et al., 2004).

The pivotal position of tour operators and their influence in the overall tourism value chain can make them drivers of sustainability agenda in the entire tourism sector. They have the power to choose suppliers and direct tourists to destinations that practice sustainability. Therefore, this paper argues that when tour operators are positioned as drivers of sustainability agenda, they can use their influence to trigger positive changes in attitudes and practices towards sustainable tourism practices. The authors focus on the less visible but very extensive influence that tour operators (small/large) have on other stakeholders that could strategically help Kenya's tourism industry move towards sustainability.

\section{LITERATURE REVIEW}

\subsection{Tour Operators in the Tourism Value Chain}

Tour operators play a pivotal role in the tourism supply chain. Majority of tourism product suppliers in Africa greatly rely on tour operators in packaging and selling their products. Tour operating involves buying tourism services from suppliers (hotels, airlines, attractions) in bulk, assemble in attractive holiday packages, then sell directly to customers or through travel agents (Wijk and Persoon, 2006). The supply chains are diverse and fragmented, including accommodation, transport, excursions/activities, food and craft and other ancillary services. Tour operators possess the knowledge of market trends, risk partakers of primary suppliers and also provide front-end and promotional budgets (Bastakis et al., 2004).

Tour operators are influencers or major determinants of tourism destination choice by directing market flows in the travel distribution system (Buhalis, 2000). In terms of destination reputation, tour operators positively or negatively influence destination image (Mintel 2006). They further influence clients' mode of transport, handicraft shops their clients visit, type of accommodation and food, activities and sightseeing, and other ancillary services (Font et al., 2008). In destinations like European Union (UE), under the EU Package Travel Directive, tour operators have legal liability for their suppliers' performance (Font et al., 2008). Because of this, tour operators hold greater responsibility and possibility for triggering essential changes in perceptions and actions of tourists and suppliers/producers towards more sustainable tourism practices (Font et al., 2008; Sigala, 2008; Tepelus, 2005; Wijk and Persoon, 2006). As buyers in travel distribution system, they can advise suppliers on how to be more eco-efficient in order to control production costs (TOI, 2003).

Tour operators also have greater lobbying power to protect tourism main assets against the impacts of other economic activities, persuasive power based on their connections with millions of consumers and numerous suppliers, and great economic power (especially large scale operators) hence in ideal position to disseminate sustainability attitudes in the entire tourism industry (Bastakis et al., 2004; Buhalis, 2000; Font et al., 2008; Tepelus, 2005; Wijk and Persoon, 2006). Because of this influence, sustainability issues in tourism can no longer be the sole responsibility of destinations. As key stakeholders, most tour operators now understand that it is precisely their responsibility because they are intermediaries, working closely with both tourists and tourism service suppliers (Budeanu, 2005; Cochrane, 2006; Font and Cochrane, 2005; Swarbrooke, 1999)

\subsection{Sustainable Tourism Certification of Tour Operators in Kenya}

The sustainable certification in Kenya is an emerging concept but increasingly gaining support. Certification is broadly defined as a voluntary procedure 'that assesses, audits, and gives written 
assurance that a facility, product, process, or service meets specific standards' (Mahony, 2007:3 94; Bien, 2007: 7). Dodds and Joppe (2005: 16) further describe certification as 'the process of assuring consumers and industry that the company being assessed has met a set of minimum standards'. Certification concept is regarded as a double strategy to provide tourism businesses and consumers with an objective source of quality and sustainability assurance in tourism marketplace (Font and Wood, 2007). Progressively, policy makers and non-governmental organizations are supporting certification to promote sustainable tourism production and consumption in Kenya. In order to develop sustainable tourism certification, pioneer researchers noted that the process begins by setting sector relevant and achievable standards by certification body and ensuring such standards are met (Font, 2002; Toth, 2002).

Tour operators' certification in Kenya is done by Travelife, as an international certification scheme based in The Netherlands, in collaboration with Ecotourism Kenya (EK) and Kenya Association of Tour Operators (KATO). The process involves setting indicators that can credibly and effectively measure the standards to be achieved by tour operators before certification. Tour operators (applicants) are trained/coached on the standards to adopt in their operations and then apply for certification. To make the process reliable, the application is then reviewed before an independent auditor who has been trained, tested and deemed competent carries out the audit. Previous research indicates that for certification programs to be considered reliable, they need to have a third-party audit, effective assessment and clearly defined accreditation criteria (Dodds and Joppe, 2005). The certification body (Travelife) then verifies online reporting by applicants and when satisfied provides accreditation/certification. Travelife certification is within three categories namely: Travelife Engaged; Travelife Partner and Travelife Certified. Certification programs usually awards a marketable logo to companies that meet or exceed baseline standards (Mahony, 2007; Bien, 2007). Therefore, for Travelife certification, only at Travelife partner and certified recognition stages does the tour operator allowed to use Travelife partner logo and Travelife certified logo respectively.

The overall aim is that such tour operators will be recognized in the overall tourism value chain in terms of clarity to their suppliers and inbound tour operators as well as value addition to customers, justify differential pricing and avoid green washing (Travelife, 2019). Currently Travelife is the only certification body for tour operators in Kenya. The program is broadly about sustainability issues with eleven (11) indictors and one hundred and eighty four (184) actions. As indicated by Vorley, Roe and Bass (2002) and Bien (2003), the certification program seems to be based on process and performance indicators where tour operators make a commitment to improvement by putting in place management system to ensure progress. It also measures if a tour operator has met a threshold level based on specific actions to warrant certification at the level of engaged, partner or certified. A tour operator at lower certification level can progressively work towards the highest certification level. For a certification system to be credible, Toth (2002) identified essential elements, which include adequate and appropriate standards; recognition by relevant agencies and customers; appeals mechanisms; trained and qualified assessors; defined procedures; transparency; and acceptance in the marketplace for marketing and promotional purposes. Travelife certification process is deemed credible and persuades tour operators not just to seek of certification logo but integrate sustainability agenda in all their operations.

Certification can offer numerous benefits to tour operators. For example, Dodds and Joppe (2005) indicate that the main purpose of certification is to achieve standards of performance, which meet or exceed baseline sustainability standards. WTO (2004) identified three basic purposes for tourism certification as improvement of tourism service providers' operations aimed at greater environmental, economic and social sustainability; differentiate and distinguish tourism products and services that meet environmental, social and economic standards beyond legislative requirement level and consumer orientation towards sustainability characteristics of the tourism services available on the market. Foster (2003) also noted that certification process in beneficial to tour operators particularly in health and safety standards, staff turn-over and morale. From business perspective, research surveys among tour operators and vendors established that clients become much more engaged and loyal as they begin to understand the importance of responsible practices during their travels (EplerWood et al., 2005). Tour operators are also using responsible tourism as differentiation strategy in part of their marketing approach (UNEP, 2005) and improvement of public image among consumers, business partners and host communities (Bien, 2003). Certification also assists in raising industry environmental standards and reducing operational costs associated with water, energy and waste (Bien, 2003; Font and Buckley, 2001). 
Nevertheless, certain studies argue that consumer demand for certification take time to build, taking between 8 and 15 years and sometimes as long as 20 years to develop (Bien, 2005). Bien further states that 'safety, quality and price needs must be satisfied before consumers will consider other factors' (Bien, 2005: 17). Chafe (2004) augments that the benefits is dependent on consumers becoming aware and understanding credible certification brands. Some studies like Dodds and Joppe (2005) further notes that certification has not enabled small and medium sized tourism enterprises have greater access to market opportunities nor moved tourism industry significantly towards sustainability. Foster (2003) concludes that accreditation plays a very minor part in consumers' purchasing decision for both accommodation and tours but provides a vital role in the consumers' mind as an assurance that what is promised can actually be delivered.

\section{SUSTAINABILITY FrameWORK FOR TOUR OPERATORS}

This framework is based on the premise that tour operators in Kenya should be positioned as the drivers of sustainability agenda. They then use their influence to trigger positive change in attitudes and practices through sustainability communication in the tourism supply chain (Figure 1). Research made by Tourism Concern in 1999 reported that $80 \%$ of international travelers used the services of a tour operator, which demonstrates the significant potential for tour operators to influence a large number of customers. As buyers, tour operators can inform suppliers on how to be more sustainable in their operations. For example, TUI ATG, LTU Touristik, My Travel Northern Europe and Hotelplan (four large European tour operators) have developed environmental manuals for suppliers and have carried out assessments, with an emphasis on water/waste/ energy eco-savings that can reduce costs to the supplier (TOI, 2003).

Different type of tour operators currently operate in Kenya including inbound, outbound, domestic and ground operators as categorized by KATO. Inbound tour operators provide services (like airport transfers, accommodation, transportation, sightseeing, entertainment and insurance) to tourists on arrival to departure. This category of tour operators has business linkages with outbound tour operators which promotes multinational tours across one or more foreign countries. Domestic tour operators promote local travel within the boundaries of Kenya. They provide services like air and balloon safaris, camping safaris, beach holidays, bird watching, budget/deluxe/luxury holidays, conference, cultural tours, eco-safaris, family/group holidays, golf, honeymoon, horse riding, mountain climbing, photography, road safaris, trekking and student holidays. Ground operators are mainly destination management companies (DMCs) that take care of all local arrangements for a specific overseas tour operator. The KATO currently categorises tour operators' membership in terms of their financial turnover. The categories range from A to E. Other categorization includes associate, affiliate, provisional and corporate.

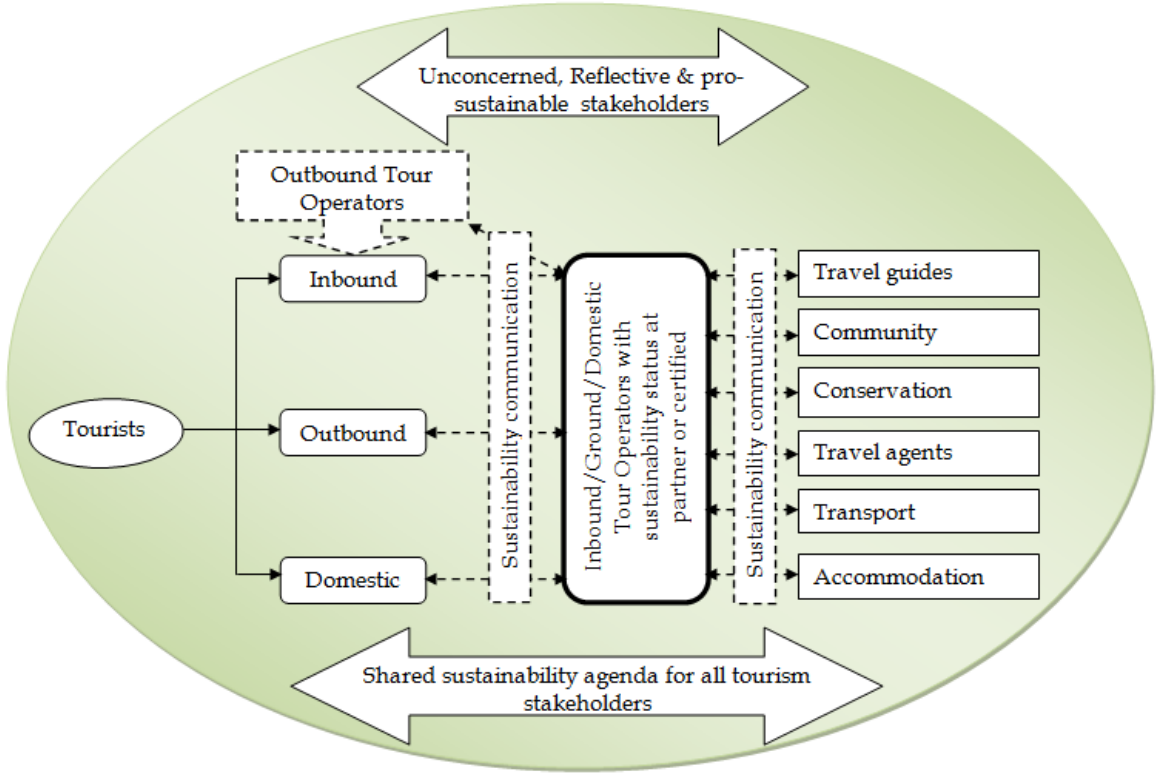

Figure1. Sustainability framework for tour operators as drivers of sustainable tourism agenda

Source: Authors

International Journal of Research in Tourism and Hospitality (IJRTH) 
With respect to tourism demand, tourists (both domestic and international) are segmented based on the concept of "sustainable intelligence" (López-Sánchez and Pulido-Fernández, 2016). The framework applied the concept further to include all stakeholders in the tourism supply chain as reflective, unconcerned and pro-sustainable stakeholders. The emphasis is that when all categories of tour operators make corporate commitment to sustainability as integral part of their operations, they are at the central role to make sustainability communication to all categories of stakeholders (tourists, travel guides, host community, conservation agencies, travel agents, transport and accommodation). This communication of sustainability message, especially among large scale tour operators, could influence the unconcerned and reflective stakeholders to be pro-sustainable in their business operations.

Overseas tour operators play key role in supplying customers to inbound/ground operators in developing countries like Kenya. They hold a leading position in their national markets. With their extensive distribution networks, their commitment to sustainability has the potential to induce behavioural changes in the tourism industry overseas and within recipient destinations like Kenya. The benefit of this extensive distribution network working for sustainability can ensure a rapid dissemination of the message to the distribution network of millions of people across the world. This eventually may create shared sustainability agenda for all tourism stakeholders.

\subsection{Successful Implementation of the Framework}

The Travelife certification program was initiated in Kenya in 2016. The number of tour operators already certified is still minimal albeit positive response from many tour companies. In order for Kenya's tour operators to be the drivers of sustainability agenda, already certified operators should strengthen business partnership/support from major pro-sustainability international tour companies supporting Travelife. Example of such companies include Apollo, Arke, TUI Travel Plc, Thomas Cook, Look Voyages, Hotelplan Suisse, Thomson, Sovereign, Kuoni, Ving, Exotissimo Travel, Airtours, KHIRI Travel, First Choice, Cosmos and Neckermann Reizen. Kenya's tour operators should take advantage of Travelife benefit of international promotion for tour companies' excellent sustainability achievement.

In addition, Travelife certification program should bring on board large scale tour operators under KATO, especially those in category A, B, C due to their large market share and influence. Tour operators should also strike to have a shared sustainability agenda, constantly communicating the message to suppliers and tourists while developing their packages, customer relations or choosing services from suppliers. There should also be greater engagement in sustainability initiatives, so as to identify business benefits. Previous research by Dodds and Joppe (2005) indicate that certification programs do not appear to offer tangible market benefits to operators. Since tour operators are profitmaking entities, it is their core business obligation to realize higher return on investment in order to be committed to the certification scheme.

\subsection{Weaknesses of the Framework Implementation}

Some of the possible weaknesses in the operationalization of the framework exist. For example, the nature of the tour operating industry in Kenya, such as high levels of price competition, fluctuating market demand, and a possible short-term outlook to business relationships, could pose a considerable threat to sustainability agenda. In addition, implementation of sustainability certification might be challenged by financial, operational and human resource capacity limitations faced by tour operators in Kenya (both internally and in supplier operations). In the medium term at least, costs, facilities and service levels will be given priority over sustainability criteria in purchasing decisions by tour operators. Moreover, the effects of $4^{\text {th }}$ industrial revolution on tour operators' business operations in terms of technological revolution that will fundamentally alter global travel and tourism industry such as online marketing, web-based bookings and mobile commerce.

\section{CONCLuSion}

Due to international demand for environmentally responsible and ethically traded tourism products, tour operators can take advantage of this demand to develop and sell sustainable tourism packages. Tour operators also have power to trigger attitude change and actions of tourist and destination producers towards a more sustainability practices. Through their actions, they can have a direct 
impact on sustainability by managing their office suppliers as well as significant influence on sustainability through the supply chain. Change in their key operating areas like in product development, internal management, supply chain management, co-operation with destinations and customer relations towards sustainability will drive the overall sustainability agenda in the tourism value chain. This paper recommends future empirical research in Kenya to establish percentage of consumer demand for certified products. This is because the quest for sustainable certification is mainly driven by the certification agency, non-governmental organizations like EK and tour operators' governing body KATO. Moreover, further research should be undertaken to establish whether sustainable tourism products has acted as a differentiation strategy for certified tour operators over uncertified tour operators to gain market share.

\section{REFERENCES}

[1] Akama, J. S., Maingi, S. and Camargo, B. A. (2011). Wildlife conservation, safari tourism and the role of tourism certification in Kenya: A postcolonial critique. Tourism Recreation Research, 36(3), 281-291.

[2] Ariya, G., Sitati, N. and Wishitemi, B. (2017). Tourists' Perceived value of wildlife tourism product at Lake Nakuru National Park, Kenya. European Journal of Tourism, Hospitality and Recreation, 8(2), 147156.

[3] Bastakis, C., Buhalis, D. and Butler, R. (2004). The perception of small and medium sized tourism accommodation providers on the impacts of the tour operators' power in Eastern Mediterranean. Tourism Management, 25, 151-170.

[4] Bhandari, K. (2014). Tourism and National Identity: Heritage and Nationhood in Scotland. Bristol: Channel View Publications.

[5] Bien, A. (2003). A simple user's guide to certification for sustainable tourism and ecotourism. Washington DC: The International Ecotourism Society.

[6] Bien, A. (2005). Marketing Strategy for Sustainable and Ecotourism Certification, EcoCurrents First Quarter 2005. Washington DC: The International Ecotourism Society.

[7] Bien, A. (2007). Simple users guide to certification for sustainable tourism and ecotourism. Retrieved 16 April 2020, from http://www.responsibletravel.org/ projects/documents/certification_handbooks/andbook_ 1_Simple_users_guide_to_certification_final.pdf

[8] Boniface, B. and Coope, C. (2005). Worldwide destinations casebook: The geography of travel and tourism. Burlington: Elsevier Butterworth-Heinemann.

[9] Budeanu, A. (2005). Impacts and responsibility for sustainable tourism: A tour operator's perspective. Journal of Cleaner Production, 13(2), 89-97.

[10] Buhalis, D. (2000). Relationships in the distribution channel of tourism: Conflicts between hoteliers and tour operators in the Mediterranean Region. In J. Crotts, D. Buhalis and R. March (Eds), Global Alliances in Tourism and Hospitality Management (pp. 113-139). New York: Haworth Press.

[11] Chafe, Z. (2004). Consumer demand and operator support for socially and environmentally responsible tourism. CESD/TIES Working Paper No. 104, Washington.

[12] Cochrane, J. (2006). How can tour operators contribute to sustainable development? Communicating Development Research, UNEP and Ministère de l'Écologie et du Development Durable, id research highlight.

[13] Dodds, R., and Joppe, M. (2005). CSR in the tourism industry: The status of and potential for certification, codes of conduct and guidelines. Washington, WA: IFC, World Bank.

[14] Epler Wood, M., Wight, P. and Corvetto, J. (2005). A Review of markets, business, finance and technical assistance models for Ecolodges in developing countries, Washington, DC: IFC, World Bank.

[15] Font, X. (2002). Environmental certification in tourism and hospitality: Progress, process and prospects. Tourism Management, 23 (3), 197-205.

[16] Font, X. and Buckley, R. C. (2001). Tourism ecolabelling: Certification and promotion of sustainable management. Oxon: CABI Publishing.

[17] Font, X. and Cochrane, J. (2005). Integrating sustainability into business: A management guide for responsible tour operations. Paris, UNEP, WTO.

[18] Font, X., Tapper R., Schwartz K. and Kornilaki M. (2008). Sustainable supply chain management. West Sussex: John Wiley and sons.

[19] Font, X. and Woods, E. M. (2007). Sustainable tourism certification marketing and its contribution to SME market access. In R. Black and A. Crabtree (Eds), Quality assurance and certification in ecotourism. New York: CABI Publishing. 
Towards Sustainability Framework for Tour Operators as Drivers of Sustainable Tourism Agenda in Kenya

[20] Foster, D. (2003). The customers perception of tourism accreditation. Retrieved $16^{\text {th }}$ April 2020, from https://pdfs.semanticscholar.org/f4e9/ad833542b8c4d8158bb7924ba 53229e3f2d0.pdf

[21] López-Sánchez, Y. and Pulido-Fernández, J. I. (2016). In search of the pro-sustainable tourist: A segmentation based on the tourist "sustainable intelligence". Tourism Management Perspective, 17, 59-71.

[22] Mahony, K. (2007). Certification in the South African tourism industry: The case of fair trade in tourism. Development of Southern Africa, 24(3), 393-408.

[23] Miller, G. (2003). Consumerism in sustainable tourism: A survey of UK consumers. Journal of Sustainable Tourism, 1, 17-39.

[24] Miller, G. and Twining-Ward, L. (2005). Monitoring for sustainable tourism transition. New York: CABI Publishing.

[25] Mintel, (2001). Ethical Tourism. London: Mintel International Group Ltd. Retrieved 16 April 2020, from http://www.mintel.com.

[26] Mori, (2000). Corporate Social Responsibility: Update, London: Mori. Retrieved 16 April 2020, from http://www.ipsos -mori.com Accessed March 2019.

[27] Sigala, M. (2008). A study chain management approach for investigating: The role of tour operators on sustainable tourism the case of TUI. Journal of Cleaner Products, 16(15), 1589-1599.

[28] Swarbrooke, J. (1999). Sustainable tourism management. Oxon: CABI Publishing.

[29] Tearfund, (2001). Tourism: Putting Ethics into Practice. Middlesex: Tearfund.

[30] Tepelus, C. (2005). Aiming for sustainability in tour operating business. Journal of Cleaner Production, 13(2), 99-107.

[31] Toth, R. (2002). Exploring the concepts underlying certification. In M. Honey (Ed.) Ecotourism and Certification: Setting Standards in Practice (pp. 73-102). Washington: Island Press.

[32] TUI Travel PLC (2010). Responsible Leadership. Sustainable Development Report 2009. Crawley: TUI Travel PLC.

[33] Tour Operators Initiative (TOI) (2003). Sustainable tourism, the tour operators. Paris, UNEP.

[34] Travelife. (2019). Travelife for tour operators and travel agents. Retrieved 18 August 2019, from http://www.travelife.info.

[35] UNEP (2005). Marketing Sustainable Tourism Products. United Nations Environment Programme, Paris. Retrieved 16 April 2020, from http://www.uneptie.org/pc/ tourism/private_sector/Marketing\%20su stainable\%20tourism\%20htm.htm

[36] Vorley, B., Roe, D. and Bass, S. (2002). Standards and Sustainable Trade. London: IIED.

[37] Wijk, J. and Persoon, W. (2006). A Long haul destination: Sustainable reporting among tour operators. European Management Journal, 24(6), 381-395.

[38] WTO (2004). Indicators of Sustainable Development for Tourism Destinations. Madrid: WTO.

[39] Yeoman, I. (2008). Tomorrow's Tourist: Scenarios and Trends. Oxford: Elsevier.

Citation: George Ariya, et.al. "Towards Sustainability Framework for Tour Operators as Drivers of Sustainable Tourism Agenda in Kenya". International Journal of Research in Tourism and Hospitality (IJRTH), vol 7, no. 1, 2021, pp. 09-15. doi: https://doi.org/10.20431/2455-0043.0701002.

Copyright: (C) 2021 Authors. This is an open-access article distributed under the terms of the Creative Commons Attribution License, which permits unrestricted use, distribution, and reproduction in any medium, provided the original author and source are credited. 